\section{PRIDE OF LIONS TAKES PRIDE OF PLACE WITH CAMDEN DENTISTS}

Two mature male lions and a lioness have moved in to a Bloomsbury Dental Practice - but neither the lions nor the general public have anything to fear. The lions are cuddly toys that have been sent to the Forest and Ray dental practice in Gilbert Place by the Born Free Foundation in return for the practice adopting three African lions.

Dentists at the practice decided on the adoptions as a counter to American dentist and big game hunter Walter Palmer, who caused a world-wide backlash when he unlawfully killed a prized and protected lion called Cecil. The Born Free connection all came about after Customer care Manager Christopher Hall spotted an online photograph of an advertising sign for the 'Hagerty Family Dental' surgery in Arkansas, USA.

Christopher said: 'I'd been following the story of Cecil the lion and Walter Palmer, and the public's reaction to it. I discovered that another American dentist had added a tongue-in-cheek addition to the sign outside his practice - he had put underneath "By the way, I don't hunt lions", and this went viral.'

Then a past patient got in touch with Chris via Facebook asking whether all dentists were like Walter Palmer, Chris said 'no they're not! Most dentists are caring people.' He added: 'I talked to our dentists and they were quite shocked that people might think that. They all said lions are very beautiful animals and there aren't many of them left. It would be a terrible shame to kill such an exotic animal.

'I started thinking about what we could do to show that we care about wildlife, so we contacted the Born Free Foundation. They were really happy to hear from us, and we decided to sponsor three lions - or rather two lions and a lioness, named Dolo, Sinbad and Shada.'

Resident dentist at the practice Dr Nick Kasiteridis said: 'They've sent us two cuddly lions and a lioness to represent our adoptees, all of which are safely looked after at the Born Free Foundation's Wildlife Rescue Centre near Addis Ababa in Ethiopia. We have adoption certificates and some rather magnificent photos of the lions and an adoption pack, and we will be getting periodic updates on how they are getting on.

'Sponsoring three lions does not represent a massive donation but we are discussing fundraising for the Foundation on a regular basis, anything from just having a collecting tin at our surgery to holding fund-raising days and events. It is early days yet but younger patients in particular love the cuddly lions, and we are happy for them to take photographs of themselves posing with them in return for a small donation.

'The Born Free Foundation is also interested in joining us in publicising this more widely and we are looking to them for advice on fund-raising ideas. It would be great if we could get dentists in other parts of the UK and indeed around the world joining in to support the foundation in their work, helping to protect lions and wildlife.

'Instead of being ashamed of what Walter Palmer's exploits did to the reputation of the profession, we can be proud that a pride of lions has moved into a dental surgery in Camden!'

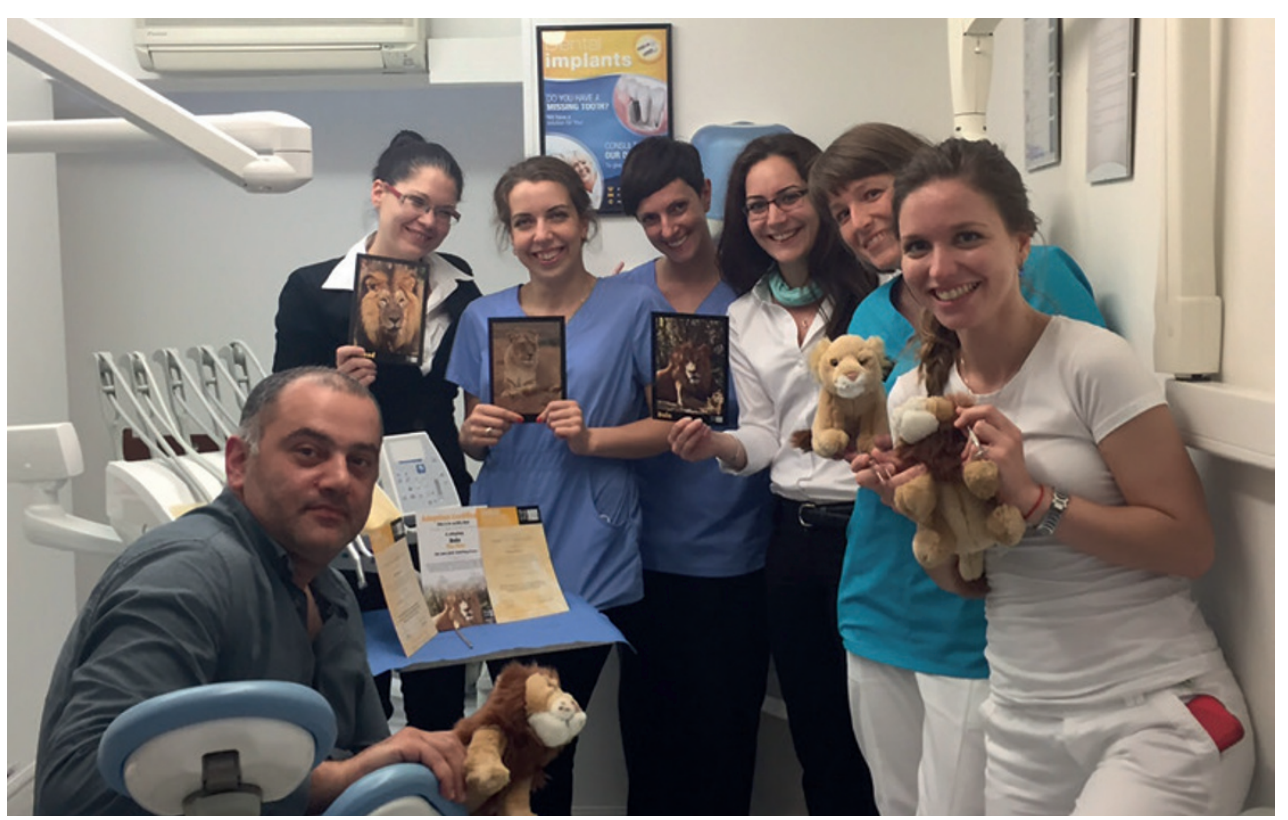

\section{BITING BACK}

The Mouth Cancer Foundation is launching Bite Back at Mouth Cancer, a simple head and neck cancer check which can be carried out by anyone at home, at any time, ideally once per month.

There are easy to do self-check tests for a variety of other cancers but there is nothing similar for mouth, head or neck cancer. Bite Back at Mouth Cancer shows members of the public what to look for and how to seek help if they find something out of the ordinary. They will become familiar with the signs and symptoms to look out for and learn to act sooner.

GP and TV doctor Dr Dawn Harper is backing the initiative and has taken part in a video to clearly show how to carry out the examination. She said: 'It is recommended that the self-check is done once a month after teeth have been cleaned and by everyone over the age of 16 years. It takes less than two minutes. To carry out the mouth test all you need is a mirror, good light source and clean fingers. It is that simple. At each step you are inspecting and feeling for any lumps, red or white patches, changes in colour or texture, lingering ulcers or anything unusual.'

The Bite Back at Mouth Cancer self-examination has been devised by Mouth Cancer Foundation Ambassadors, Consultant Oral and Maxillofacial Surgeon, Mahesh Kumar and Dentist Philip Lewis.

Philip Lewis said: 'Encourage patients to make a note of anything unusual. If they have recently had a cold, sore throat, ulcer or swollen glands, bitten or scolded themselves for example, tell them these should heal within three weeks. If they have any concerns encourage them to book an appointment.'

To view and download the self-check instuctions, leaflet and posters visit http://www. mouthcancerfoundation.org/ get-involved/bite-back-mouthcancer. 